\title{
Victimization and Post-traumatic Stress Disorder of Victims of Terrorism in Indonesia
}

\author{
Ufran $^{1}$, Erlyn Indarti ${ }^{2}$, Adji Samekto ${ }^{3}$ \\ ${ }^{1}$ Lecture at Faculty of Law, University of Mataram 83126, Indonesia, ${ }^{2}$ Lecture Faculty of Law, Diponegoro \\ University, Semarang 50275, Indonesia, ${ }^{3}$ Lecture Faculty of Law, Diponegoro University, Semarang 50275 , \\ Indonesia
}

\begin{abstract}
Terror attacks result in prolonged traumatic effects on both victims and survivors. Previous studies have analyzed the effects of terror attacks on the psychological condition of post-traumatic stress disorder from exposure to terrorist attacks. This article discusses victims of terrorism in Indonesia based on data from 2008-2018. The use of data over the span of several years is important to determine the trend of victimization so that a response can be made to reduce the suffering of victims. This perspective also includes counterterrorism efforts to minimize the suffering of victims directly or indirectly due to terrorism. The criminal justice system can also reform paradigmatically, providing fulfillment of the rights of victims in accordance with applicable legal norms.
\end{abstract}

Keywords: Victims, post-traumatic stress disorder, legal protection, victimization, terrorism.

\section{Introduction}

Terror attacks result in prolonged traumatic effects on both victims and survivors ${ }^{1-6}$. However, active efforts so far have been aimed at handling and preventing action, and have not yet fully addressed these psychological effects. Deliberate targeting of innocent people in general plays a central role in terrorists' ability to terrorize. However, to date, little attention has been focused on victims of terrorist attacks whether they are survivors themselves or family members, friends or colleagues who have been directly exposed to this violence. It is appropriate for the justice system to change paradigmatically, from the discourse of protecting perpetrators to serving victims. Fulfilling the rights of victims is prioritized in the form of physical, economic and psychological recovery ${ }^{7-11}$. The discourse of serving terrorism victims must also be placed in the framework of prevention and counteracting terrorism itself as an ideology that spreads fear.

\section{Corresponding Author:}

Urfan

Lecture at Faculty of Law, University of Mataram

83126, Indonesia

e-mail: ufran.unram@gmail.com
Many previous studies have analyzed the effects of terror attacks on the psychological condition of victims. ${ }^{12-16}$ Some have also investigated post-traumatic stress disorder from exposure to terrorist attacks. ${ }^{17-22} \mathrm{It}$ should also be noted that the provision of psychological support to terrorist victims in developing countries is less than that of developed countries. This is linked not only to a lack of social and financial resources, but also to a lack of policies and legal protections that specifically accommodate these interests. ${ }^{23}$ This article reviews the problem of the victimization of terrorism in Indonesia. Terrorism has long been described as a violence choreographed by groups of people who wish to influence fundamental political change. The violence perpetrated by terrorists is designed not only to draw attention to them. Terrorism also aims, to coerce and intimidate, to create an atmosphere of fear and worry that terrorists can take advantage of. ${ }^{24,25}$

Perpetrators and Prevalence of Terror Attacks: Terrorist attacks have two patterns, namely focused and indiscriminate aspects. Terror is used as an instrument for politically motivated actions, targeting government officials, political figures as well as for the purpose of achieving certain political goals. Contemporary terrorism is characterized by the increasing frequency 
and magnitude of violence that can happen to anyone at random. ${ }^{26-30}$ Terrorism in Indonesia refers to terror incidents that occur in Indonesian territory or attacks against Indonesian people or interests abroad. These acts of terrorism often target the government or foreigners in Indonesia, especially tourists. The perpetrators of terror were traditionally carried out by militias who politically opposed the interests of the government.

It is noted that several terrorist groups that often carry out attacks are separatist movements and Islamic-based militia operating in Indonesia. These groups are often held responsible for terrorist attacks, such as bombings and shootings, in Indonesia. ${ }^{31}$ Recent terrorism can be attributed in part to the terror group such as Jemaah Islamiyah which is affiliated with Al-Qaeda and/or ISIS. There were eight of the biggest terrorist attacks to have occurred in Indonesia between 2001-2017. Terror attack incidents, which caused the most casualties, ranged from 2000 to 2001 . The number of incidents was 101 in 2000, while in 2001 there were 105 incidents. The number of terrorism attacks that occurred during the period 20002018 (see graphic) was around 538 incidents. The incident that caused the death toll was recorded on December 24, 2002 , Jemaah Islamiyah spread terror to several areas. There were 40 incidents of bomb detonation carried out by JI. The target of the bomb detonation was the church where Christians worship. From 2002 to 2007, terror incidents continued to decline. There were around 43 terror incidents recorded in 2002 and only 2 incidents recorded in 2007. Unfortunately, in 2008, terror attacks increased again and the number was quite dynamic until May 2018. The data also shows that terror incidents in Indonesia show a better index. ${ }^{32}$

Victimization of Terrorism: Some experts argue that victimization is an invasion of a victim's personal self or victimizations are invasions into the self of the victim. ${ }^{33-37}$ The victimization of terrorism is somewhat unique and different from the victimization of ordinary crimes. Victims of terrorist attacks are usually not specifically targeted based on individual characteristics, but they are "accidental" victims. Just happen to be in the wrong place at the wrong time. These victims, however, function as instruments designed to influence third party actors. $^{25,27,28,38-40}$

It is this element of uncertainty and randomness in the selection of victims that gives terrorism more power. A force that is multiplied by mass media broadcasts and reruns of its victimization. Direct victims of terrorist attacks are rarely the final targets of violence. In contrast, the act of selecting targets serves as reinforcement to convey messages and to influence a wider audience, such as a country that is an opponent of a terrorist organization. This victimization pattern can also be seen from the modus operandi of terror carried out by organizations or groups that have been antigovernment since the beginning. They launched their actions to convey anti-Indonesian government political propaganda. $^{26,27}$

Victims in terrorist attacks serve as symbols of common group or class characteristics, which in turn form a basis for their selection as victims. ${ }^{39}$ In this case, victims of terrorism become instrumental targets/ targets. ${ }^{41}$ When viewed based on the number of victims, both dead and injured, 2002 was the year with the most victims, with 781 victims, 246 died and 535 were injured. The highest number of victims occurred during the bomb blasts in two places, namely Paddy's Pub and Sari Club on Jalan Legian, Kuta, Bali. This incident is known as the Bali Bombing I. The incident masterminded by Jamaah Islamiyah (JI) caused 202 people to lose their lives and injure 300 victims. The second highest number of victims occurred in 2000 with a total of 482 victims, namely 146 victims and 336 injured. In 2004, a terror incident also left 238 injured. The major attack was a suicide bomb that was detonated by means of a large car bomb outside the Australian Embassy in Jakarta. This incident caused 180 people to be injured.

Typology of Victims: Given the erratic pattern of attacks and the absence of victims who were specifically targeted as victims of other types of crimes, discussing terrorism victims is unique in nature, relating to their specific harmful causes. An expert argue that there are two basic typologies to distinguish victims of terrorism namely primary victims or primary victims and secondary victims ${ }^{26}$. Primary victimization often occurs as a result of initial victimization. Secondary victimization, which sometimes blurs the line between victim and perpetrator, refers to the social damage that occurs, not as a direct result of the crime, but through the response of social institutions and individuals to the victim ${ }^{27,42}$. In addition to the typology proposed, ${ }^{26}$ there is also an alternative typology of victims of terrorism put forward by Ben Emmerson, a UN Special Rapporteur on the promotion and protection of human rights and basic freedoms in countering terrorism. ${ }^{43}$ In the report numbered (A/HRC/20/14), the Special Rapporteur identifies the following four main categories of victims 
of terrorism: Direct victims of terrorism: Secondary victims of terrorism; indirect victims of terrorism and potential victims of terrorism. ${ }^{43}$

Post-Traumatic Stress Disorder on the Victims of Terrorism: The main objective of counter-terrorism efforts is to prevent victimization. Data on the number of victims who died and were injured due to terrorist attacks from 2000 to 2018 in Indonesia. The significant impact for victims of terrorism is in addition to losing their lives, serious injuries but also prolonged feelings of trauma. The lives of victims have changed forever. ${ }^{42,44}$ Victims of crime may have difficulty sleeping or concentrating, may be easily startled, may fail to participate in activities they once enjoyed, and may feel their self-esteem has dropped. ${ }^{42,45,46}$ Some victims may also experience posttraumatic stress disorder which, in addition to depressive symptoms, may also include disturbing phenomena such as flashbacks and nightmares, and which can last for months or years. ${ }^{47}$ Unfortunately, even though the victims of terrorism experience a significant impact, the Indonesian criminal justice system has not guaranteed the rights that must be received by victims such as compensation or restitution. Until now, only 56 victims of terrorism have received compensation from the government in accordance with Government Regulation Number 77 of 2018.48

\section{Conclusion}

The results showed that victimization of terrorism in the 2008-2018 periods experienced a downward trend. Protection and fulfillment of the rights of victims of terrorism are still limited to victims of death and injury, not including indirect victims who are also affected by terrorist attacks. In the future, the criminal justice system must be able to answer the challenges and complexities of the victimization of terrorism which can be fluid and at any time in accordance with the threat of terrorism that can occur at any time. This results are theoretically important to include counter-terrorism actions to minimize the suffering of victims directly or indirectly due to terrorism. Moreover, it is suggested that the reform of criminal justice system paradigmatically to provide fulfilment of the rights of victims in accordance with applicable legal norms.

Conflict of Interest: There is no conflict of interest.

Source of Funding: This research was funded by the Diponegoro University Faculty of Law Research Grant Fund for the 2020 Fiscal Year.
Ethical Clearance: Ethical Clearance from the institutional ethical committee obtained for the study.

\section{References}

1. Fremont WP. Childhood reactions to terrorisminduced trauma: A review of the past 10 years. Journal of the American Academy of Child \& Adolescent Psychiatry. 2004 Apr 1;43(4):381-92.

2. Kaitz M, Levy M, Ebstein R, Faraone SV, Mankuta D. The intergenerational effects of trauma from terror: A real possibility. Infant Mental Health Journal: Official Publication of The World Association for Infant Mental Health. 2009 Mar;30(2):158-79.

3. Shechory-Bitton M. The impact of repetitive and chronic exposure to terror attacks on Israeli mothers' and children's functioning. Israel Journal of Psychiatry and Related Sciences. 2013 Jan 1;50(3):157-63.

4. Dyregrov K, Dyregrov A, Kristensen P. Traumatic bereavement and terror: The psychosocial impact on parents and siblings 1.5 years after the July 2011 terror killings in Norway. Journal of Loss and Trauma. 2015 Nov 2;20(6):556-76.

5. Marshall RD, Bryant RA, Amsel L, Suh EJ, Cook JM, Neria Y. The psychology of ongoing threat: relative risk appraisal, the September 11 attacks, and terrorism-related fears. American Psychologist. 2007 May;62(4):304.

6. Slone M, Mann S. Effects of war, terrorism and armed conflict on young children: a systematic review. Child Psychiatry \& Human Development. 2016 Dec 1;47(6):950-65.

7. Butler L, Morland L, Leskin G. Psychological resilience in the face of terrorism. Psychology of terrorism. 2007:400-17.

8. Gurtner Y. After the Bali bombing-the long road to recovery. Australian Journal of Emergency Management, The. 2004 Nov;19(4):56.

9. Butler AS, Panzer AM, Goldfrank LR. Preparing for the psychological consequences of terrorism: A public health strategy. National Academy of press; 2003.

10. Uriarte JD. The Psychosocial Recovery Processes in Victims of Violence and Terrorist Acts. VV. AA., Violence and Communication, Reno, Center for Basque Studies. 2012:105-27.

11. Thenarianto JJ. Bouncing back from a terror attack: 
community recovery following the 2018 Surabaya attacks. In Prepared For Evolving Threats: The Role Of Behavioural Sciences In Law Enforcement And Public Safety-Selected Essays From The Asian Conference Of Criminal And Operations Psychology 20192020 Aug 24 (p. 99). World Scientific.

12. Thoresen S, Jensen TK, Wentzel-Larsen T, Dyb G. Parents of terror victims. A longitudinal study of parental mental health following the 2011 terrorist attack on Utøya Island. Journal of anxiety disorders. 2016 Mar 1;38:47-54.

13. Paz García-Vera M, Sanz J, Gutiérrez S. A systematic review of the literature on posttraumatic stress disorder in victims of terrorist attacks. Psychological reports. 2016 Aug;119(1):328-59.

14. Díaz D, Stavraki M, Blanco A, Bajo M. 11-M victims 3 years after Madrid terrorist attacks: looking for health beyond trauma. Journal of Happiness Studies. 2018 Mar 1;19(3):663-75.

15. Moya A. Violence, psychological trauma, and risk attitudes: Evidence from victims of violence in Colombia. Journal of Development Economics. 2018 Mar 1;131:15-27.

16. Bajo M, Blanco A, Stavraki M, Gandarillas B, Cancela A, Requero B, Díaz D. Post-traumatic cognitions and quality of life in terrorism victims: the role of well-being in indirect versus direct exposure. Health and quality of life outcomes. 2018 Dec 1;16(1):96.

17. Skogstad L, Heir T, Hauff EV, Ekeberg Ø. Posttraumatic stress among rescue workers after terror attacks in Norway. Occupational medicine. 2016 Oct 1;66(7):528-35.

18. Durodié B, Wainwright D. Terrorism and posttraumatic stress disorder: a historical review. The Lancet Psychiatry. 2019 Jan 1;6(1):61-71.

19. Løvstad M, Månum G, Wisløff-Aase K, Hafstad GS, Ræder J, Larsen I, Stanghelle JK, Schanke AK. Persons injured in the 2011 terror attacks in Norway-Relationship between post-traumatic stress symptoms, emotional distress, fatigue, sleep, and pain outcomes, and medical and psychosocial factors. Disability and rehabilitation. 2019 Apr 23:1-9.

20. Dale MT, Nissen A, Berthelsen M, Heir T. Posttraumatic stress reactions and doctor-certified sick leave after a workplace terrorist attack: Norwegian cohort study. BMJ open. 2020 Feb 1;10(2).

21. Aubert L. Associated factors with Post traumatic stress and anxiety disorders in first responders following terror attacks in Paris, January 2015Lyderic Aubert. European Journal of Public Health. 2017 Nov 1;27(suppl_3).

22. Evrin T, Demirel B, Y1lmaz B, Öztürk L, Korkmaz A, Unluer EE, Katipoglu B, Palabiyikoglu R, Uzunget SC, Kazancı E, Derdiyok EB. Posttraumatic stress disorder after terrorist attack in healthcare professionals. Disaster and Emergency Medicine Journal. 2017;2(1):11-8.

23. Jupp J. Strengthening Protection and Support for Victims of Terrorism in Criminal Proceedings in Afghanistan. Studies in Conflict \& Terrorism. 2019 Sep 7:1-20.

24. Hoffman B, Kasupski AB. The victims of terrorism: An assessment of their influence and growing role in policy, legislation, and the private sector. Rand Corporation; 2007 Dec 13.

25. Letschert R, Staiger I, Pemberton A, editors. Assisting victims of terrorism: towards a European standard of justice. Springer Science \& Business Media; 2009 Dec 4.

26. Schmid A. Magnitudes and focus of terrorist victimization. Nato security through science series e human and societal dynamics. 2006;13:3.

27. Ewald, U. and Turković, K. eds., 2006. Largescale victimisation as a potential source of terrorist activities: importance of regaining security in postconflict societies. IOS press.

28. Staiger I. Restorative justice and victims of terrorism. InAssisting Victims of Terrorism 2009 (pp. 267-337). Springer, Dordrecht.

29. Spalek B, Limbada Z, Mcdonald LZ, Silk D, $\mathrm{Da}$ Silva R. Impact of counter-terrorism on communities: methodology report. Institute for Strategic Dialogue, Open Society Foundations. 2012.

30. Varona G. ETA terrorism victims' experience with restorative encounters in Spain. Justice for Victims: Perspectives on Rights, Transition and Reconciliation. London: Routledge. 2014 Jun 27:322-54.

31. ARCGIS. (n.d). 2001 - 2017 Terrorist Attacks in Indonesia, https://www.arcgis.com/apps/ MapJournal/index.html?appid=9885af5ab8764ce4 92cec0fdbc938903 
32. Jost J. Institute for Economics \& Peace: Global Terrorism Index 2015. SIRIUS-Zeitschrift für Strategische Analysen. 2017 Feb 21;1(1):91-2.

33. Kirchhoff GF. Victimology-History and basic concepts. Kirchhoff et al. 1994.

34. Pemberton A, Vanfraechem I. Victims' victimization experiences and their need for justice. Victims and restorative justice. 2015 May 15:1547.

35. Wemmers JA. A short history of victimology. Victimology, Victim Assistance and Criminal Justice: Perspectives Shared by International Experts at the Inter-University Centre of Dubrovnik. 2010 May 1.

36. Biffi E, Mulder E, Pemberton A, Santos M, Valério M, Vanfraechem I, van der Vorm B. IVOR report. Implementing Victim-Oriented Reform of the criminal justice system in the European Union.

37. Hall M. Victims and policy-making: a comparative perspective. Routledge; 2012 Aug 6. Vanfraechem I, Fernández DB, Aertsen I, editors. Victims and restorative justice. Routledge; 2015 May 15.

38. Kirchhoff GF, Kosovski E, Schneider HJ, editors. International Debates of Victimology: Papers and Essays Given at the VIIth International Symposium on Victimology in Rio de Janeiro 1991. World Society of Victimology; 1994.

39. Šeparović ZP. International Terrorism: LargeScale Victimisation. Large-Scale Victimisation as a Potential Source of Terrorist Activities, IOS Press, Amsterdam. 2006:20-9.

40. Winkel FW. Fear of crime and criminal victimization: Testing a theory of psychological incapacitation of the 'stressor' based on downward comparison processes. The British Journal of Criminology. 1998 Jul 1;38(3):473-84.

41. University Module Series. Introduction To International Terrorism, United Nations, August 2018 Education For Justice University Module Series Counter-Terrorism

42. Schmalleger F. Criminology today: an integrative introduction. Second edition. Upper Saddle River, NJ: Prentice Hall; 1999.

43. Emmerson B. Special Rapporteur on promotion and protection of human rights and fundamental freedoms while countering terrorism. Perception that refugees are more prone to radicalization wrong and dangerous-UN rights expert". UN News. 2016 Oct;24.

44. DeValve EQ. A qualitative exploration of the effects of crime victimization for victims of personal crime. Applied Psychology in Criminal Justice. 2005;1(2):71-89.

45. Petersen DL, Walker SD. The psychological and physiological impact of stress. Victim assistance: Exploring individual practice, organizational policy, and societal responses. 2003:66-94.

46. Assistance V. Exploring Individual Practice, Organizational Policy and Societal Response. Springer Series on Family Violence; Underwood, TL, Edmunds, C., Eds., New York: Springer Pub. 2003.

47. Almeida R, Moroz A. Responding to terror attacks.

48. Wahyuni F. Causes of radicalism based on terrorism in aspect of criminal law policy in indonesia. Jurnal Hukum dan Peradilan. 2019 Jul 31;8(2):196-213. 